\title{
PSYCHOANALYTIC INTERPRETATION OF LITERARY ACTIVITIES: PROBLEMS AND PROSPECTS
}

\section{Pecharskyi A. Ya.}

\section{INTRODUCTION}

In literary activities, there are a lot of artistic reminiscences falling into the plane of the so-called "poetics of non-expressed science", where, by pathologizing the social behaviour of a person at the level of interpersonal phenomena, the author-psychoanalyst tries to heal the spiritually broken state of their soul with Word. Finally, the other side of the case can be traced. The artist, like his characters, is also a human with their internal problems: neuroticism, passion, complexes, desires, failures, successes, and so on.

The anthropological meaning of psychoanalysis and literary activities is to bring benefits to the true essence of the human. English thinker E. Burke believed that art should not originate from the artistic needs of aesthetics, but from the spiritual promptings of the individual. This also applies to psychoanalysis as one of the methods of psychotherapy. However, this generates problems of the worldview. Psychoanalysis and literary activities mostly focus on the two-dimensional (body-soul) anthropological dialectics of the human life world, which does not reflect all of its existential dimensions.

Literary criticism in our study shows that the prospect of a psychoanalytic interpretation of literary activities is closely related to the Christian understanding of three-dimensional (body-soul-spirit) anthropological dialects of the human life world. It is well known that the emergence of psychoanalysis as a science owes its origin to religion. The actual Christological reconstruction of psychoanalytic paradigmatic relations in literary activities, in our opinion, will contribute to the deepening of anthropological research.

\section{Problems of the two-dimensional anthropological dialectics in psychoanalysis and literary activities}

The affinity of psychoanalysis and literary activities lies in discovering and exploring the deep, inner world of human. However, the purpose of psychoanalysis is interpretive and therapeutic effects, and the purpose of fiction is aesthetic effect. Paradigmatic relationships between these spheres 
of activity are in the process of establishing. Thus, many psychoanalytic terms are based on symbolic meanings and plots borrowed from literature and mythology: Oedipus complex (S. Freud) from the tragedy "Oedipus the King" by Sophocles, Griselda complex (J. Putnam) from the collection "Decameron" by J. Boccaccio, Shadow (C.-G. Jung) from the fairytale "Shadow" by H.-Ch. Andersen, masochism (R. Kraft-Ebing) from the novel "Venus in Fur" by L. von Sacher-Masoch, Electra complex (C.-G. Jung) from the Greek myth of Electra, Eros (S. Freud), Thanatos (V. Shtekel), narcissism (G. Ellis), erotization (G. Markuse) and others.

The shift of ideas and concepts of the psychoanalytic paradigm to the metaphysics of the artistic text is due to the fact that the structured system of poetics contains the diagnostic and therapeutic self-determination of the narrator, character/protagonist, prototype, author, etc. In this way, the artistic model of thinking goes beyond the psychoanalytic one.

Such interpretations have repeatedly been given away by the grandeur of the psychological depth of Ukrainian classics. Privileged evidence takes the story by Ivan Franko "Jay's Wing" where the therapeutic method of "paradoxical intention" is highlighted: the character of Massino overcomes his old phobia of the "fatal correspondence" by the fact that he risks to open a mysterious letter addressed to him from Port-Arthur. Similarly, "Andriy Lahovskyi" by A. Krymskyi is similar to the psychoanalytic "active technique" in the narrow Freudian sense: from the "free association method" "** to the "insight"*** of the Oedipal pathogenesis of the main character's hysteria. And in Ye. Pluzhnyk's novel "Illness", the conversations of friends with Ivan Orlovets, concerning his painful erotisized love for the notorious singer Iryna Zavadska, are deepened with

${ }^{*}$ In 1946, the well-known psychoanalyst W. Frankl invented the therapeutic method of a paradoxical intention, the essence of which is that, instead of a peculiar "escape into the disease", the patient is offered what he/she is most afraid of.

** Statements based on an arbitrary analytic account of his subjective images, fantasies, ideas, dreams, i.e. everything that comes to his mind. In classical psychoanalysis, it is an alternative to hypnosis, which provides an opportunity to translate the displaced unconscious thoughts and feelings into the realm of consciousness. The idea of free associations before the therapeutic practice and theory of Freud was interpreted by artists, in particular by I. Franko ("From the secrets of poetic creativity"), L. Berne ("How to become an original writer in three days") and others.

${ }^{* * *}$ In psychoanalysis, the state of insight is commensurate with the instant awareness and cognition of new meaning and the significance of unconscious mental processes. 
the basic principles of "focal therapy"**** in order to affirm the realistic vertical axis of the protagonist's Ego.

After all, the artistic intertextual modes of therapeutic methods, propositions, and ideas that make up the semantic core of psychoanalysis exist in numerous writings. This generates the paradigmatic relationship between thesaurus and storytelling in fiction.

However, in terms of outlook in psychoanalysis as well as in literary activities, very significant issues related to two-dimensional anthropological dialectic are highlighted. The point is that human nature is considered only in two dimensions: bodily and mental without reflecting the objective anthropological reality. After all, there were reasons for psychoanalysis in the circle of artists usually to cause a negative reaction. For example, Austrian novelist K. Kraus stated in the press: "Psychoanalysis is the ailment from which it is going to cure us". Instead, V. Pidmohylnyi, aware of the importance of instincts, lure and erotic desires in a person's unconscious mental processes, wrote that "the sexuality of psychoanalysis is not the sexuality of a brothel". E. Hemingway was skeptical about the therapeutic effectiveness of psychoanalytical science.

For reasons of logic, one should emphasize the following: certain statements are nothing more than evidence of a person's creative selfcenteredness and their inability to perform critical introspection. However, regarding the worldview position of psychoanalysis, Freud's colleague, Austrian novelist S. Zweig, was right: "As a science exclusively about the individual soul of an individual, it [psychoanalysis. - A. P.] does not know and does not want to know anything about the collective meaning or metaphysical mission of humanity; it only sheds light on the mental processes and therefore does not warm the human soul. It can only give health, but health is not enough. For happiness, for creative being, humanity needs to constantly support its belief in the meaning of existence" ${ }^{\prime \prime}$.

Finally, the problems of the deep psychology was best charactrised by G. Chesterton who said: "Psychoanalysis is a confession without absolution". Thus, the English writer and thinker unconsciously delineated the perspective of two-dimensional (body-soul) anthropological dialectics in psychoanalysis and literary activities, which is associated with the

${ }^{* * * *}$ A variety of psychoanalytic therapy focused on short-term and effective elaboration of a certain internal human conflict and unconscious processes related to it.

1 Цвейг С. Фридрих Ницше. Зигмунд Фрейд: Эссе. Санкт-Петербург: Азбукаклассика, 2001. С. 213. 
interpretation of the inner world of human: narrator, author, prototype, character/protagonist, etc. These creative-psychological phenomena, artistic forms, representations, ideological values in G. Chesterton's interpretation are mediated by the Christian imperative of "spiritual fullness", the only real Truth, which, according to St. Isaac of Syria, is getting known by the power of life.

Revealing the methodological problems of psychotherapy, M. Savchyn rightly noted that modern psychoanalysis as never before needs a spiritual worldview that must be based on the Christian tenets of faith. After all, there is a real danger of a distorted scientific interpretation of the norm of "harmonious personality" of human. "This leads", he continues, "to the fact that practicing psychologists have begun to cultivate narcissism as a social value leading to the emergence of a generation that American psychologists call the I-generation, with a distinctly individualistic, selfish, non-supportive personality without the ability to interact (assist, support, contribute) with another person who is able to laugh but is unable to rejoice and experience quiet inner joy",2.

The essence of the psychoanalytic paradigm of two-dimensional anthropological dialectics in literature lies in the internal unity of sense of the artistic text, author-artist, author-human and recipient. However, in reality, this integrity is split as a result of the spiritual decline of the individual. A lot of writers of various times have liked to assure that a true artist begins where a person ends, upholding not so much the "collectivism" of the artistic consciousness as their own self-centeredness and irresponsibility to society. This understanding of the psychology of creativity, according to thinkers, leads to the deprivation of freedom and the denial of any system of values: in this case, the very artist becomes the yardstick of all things. Well-illustrated is this problem, which became especially acute in the early $20^{\text {th }}$ century, in the "Thomistic Aesthetics and Ethics" by J. Mariten ("The Limits of Art", "The Responsibility of the Artist") and G. Chesterton ("Omar Khayyam and Sacred Wine", "Hamlet and the psychoanalyst", "Romance of rhyming poems", "Persistent in orthodoxy"); G. Marcel's "Christian humanism" ("To Tragic Wisdom and Beyond", "My Death and I"); "aesthetics of human" of G. Bell ("Frankfurt readings"); M. Bakhtin's "material aesthetics" ("Aesthetics of literary art") and others.

2 Савчин М. Методологічні та практичні проблеми психотерапії у контексті духовної парадигми психології. Психологія і суспільство. 2009. № 4. С. 232. 
In general, the writer is in some sense an icon painter of human souls, where the divine and the devilish are crossed. The magic of his artistic aesthetics blurs the diametrical opposites, bribing the reader with mesmerizing poetic power. Even Freud himself was amazed: "How the writer succeeds in doing this is his precious secret; in the technique of overcoming the repelling matter $<\ldots>$ lies true Ars poetica" ${ }^{3}$.

So we face a unique psychological phenomenon of creativity that acts in the receptive field of the addressee and the addresser. In literary theories, the intensification of search for such dualistic-creative connections established a certain strategy for the interpretation of art works, namely the agreement of the author, reader and text in the parameters of conscious and unconscious mental processes. In his wellknown dialogue "Ion", Plato caused unique shifts in the future literary and psychoanalytic methodology by observing that the artists themselves know the least how they are creating.

There are similar interpretations in writings by S. Freud, who considered the valuable cooperation of analysts and artists, because, in his opinion, the latter bring artistic material from those spiritual sources of man, which still remain a mystery for science. This prompted the founder of psychoanalysis to study in depth the masterpieces of world culture and, on their basis, to create vivid illustrations of clinical findings obtained in the process of therapeutic practices.

Outlining the narrative models of literary activities at the turn of the twentieth century, M. Tkachuk stated that the development of the structural organization of lyrical subject was unfolding within the egocentric vector "I-for-myself". This is explained by the fact that outside the Christian worldview, literary development tends to psychoanalytic understanding of the two-dimensional dialectics of literary activities, which unfolds through the artistic and aesthetic correlation of the mental and physical modes of Word. Thus, the spiritual fullness of verbal expression is lost, and the inner experience of the individual is filled with the crisis of the soul, which the Apostle Paul described as "dead spirit". Thus, gradually, there is a gap between the poetic and spiritual worlds, which becomes the main existential and artistic problem of the whole twentieth century. B.-I. Antonych said about the danger of these cultural intentions: "In modern literature, instead of respectful work and tension of feelings, there

3 Фрейд 3. Художник и фантазирование. Воспоминания Леонардо да Винчи о раннем детстве. Санкт-Петербург: “Азбука-классика”, 2007. С. 215.

${ }^{4}$ Див.: Ткачук М. Наративні моделі українського письменства. Тернопіль: ТНПУ, Медобори, 2007. С. 143. 
exists only the pursuit of sensation or even scandal in order to grab attention to oneself and become higher above others... Art has descended from the highness of the inspiration to the lowness of bazaar ambitions, to the fair of snobs and junks. All kinds of programs, theories, isms are traded among themselves as if they were street shops... Modern literature has not given and cannot give synthesis. It is confused in details, ill with analyticity",

Drawing attention to the intellectually vain character of the "avantgarde high culture" that leads to disintegration, the illness of the human spirit, B.-I. Antonych considered the main purpose of art to be the awakening in the psyche of experiences that reality did not provide. This is the manifestation of the Divine Reality. Rev. A. Men wrote: "It is achieved gradually, in strict accordance to be fully prepared for a mystical meeting. God is kind of veiled, hidden from elemental perception. Step by step, He enters the minds of humans through nature, through love, through the feeling of mystery and the experience of the Holy" .

The atheistic rationalism of art, being in the "logic of solids" (A. Bergson), caused a narrowing of the artistic and aesthetic form of expression. Therefore, "cosmopolitanism of permissiveness" was born in Western European and American cultures. This process began in the early twentieth century. However, the satisfaction of artistic and aesthetic preferences of a person is not identical to the satisfaction of their existential interest, spiritual requests.

The atheistic consciousness of scientific thinking has failed due to the relativization of classical physics associated with the recognition of A. Einstein's theory of relativity and the quantum mechanics of M. Planck, whose discoveries eroded the illusion of claims to the universal and adequate reflection of the object by scientific methods. Nowadays, modern natural sciences and humanities are not about completing scientific knowledge. E. Purlo asserted: "The object of research is not seen as a thing identical to itself, but as a process that reflects some stable states and is changing in a number of other characteristics... The central aspect of science is not the objectivized real truth, but the ratio. The principle of the truthfulness of empirical knowledge is also revised: no study can be interpreted as one that gives complete information about the independent properties of an object that make sense not in themselves, but according to the observed situation. According to V.-K. Heisenberg, "something we

\footnotetext{
${ }^{5}$ Антонич Б.-І. Криза сучасної літератури. Сучасність, 1992. № 9. С. 71-72.

${ }^{6}$ Мень А. История религии: В поисках Пути, Истины и Жизни: В 7 т. Москва Санкт-Петербург „Слово”, 1991. Т. 1. С. 63.
} 
deal with while observing is not nature itself, but nature, which is available to our method of asking questions"7.

The elucidation of the truth and meaning of life, the essence of good and evil imply not only an empirical or rational method of knowing, but also a spiritual one, since truth is immutable, understanding of it is possible only through preference for it. Only God is always the same.

The method of psychoanalytic literary interpretation is closely linked to the scientific and philosophical dimension of "subjective truth", which is constituted in speech and concerns the existence of the subject. Therefore, there is a need to translate the person's primary unconscious perception into words that has a therapeutic effect. Important in this respect is Heidegger's analysis of the word "truth" - Wahrheit, which, in his opinion, comes from the Old German 'War', which means "protection". M. Heidegger's words containing subjective truth concern both poetic thought and psychoanalytic one. The first describes the kind of making an artist internal, the true feeling of his "I" and the second one - protective function patient's resistance in the therapeutic process. The truth in the psychoanalytic method is born again and constructed on the verge of theory and practice. It is only by demonstrating practical changes that one can draw conclusions about the origin of the artist's mental and psychosomatic ailments and explain the meaning of their relationship with artistic creativity.

This state of arts triggers the dichotomy of "error" and "truth of the subject" (his life story, unfulfilled desires, internal conflicts, dreams, symptoms, forgetting, slips of the tongue, etc.), which is a key element in the methodology of this science. Paradoxically, it is an inner doubt which is revealed in the analytical discourse that reflects the truth.

Along with the process of literary modernization of the early twentieth century, where the elements of the abstract (in expressionism, Dadaism, surrealism, "the theatre of the absurd", acmeism, etc.) came to the fore more and more, a new "artistic reality" emerged which found amazing psychoanalytic parallels to the inner "mental reality" of the individual.

It soon became clear that science is not created "on the basis of rational and well-defined starting points", which are supported by facts. They merely appear to be such, as S. Freud assured, and their "meaning" is determined by the constant reference to the "material of experience" on the

\footnotetext{
${ }^{7}$ Цит. за: Пурло Е. Естественнонаучные парадигмы в психологической науке: классическая, неклассическая и постнеклассическая модели. Практична психологія та соиіальна робота. 2007. № 5. С. 17.
} 
basis of which they appear to be created whereas in reality this material "subordinates to them"

In this regard, the famous phrase by J.-V.-F. Hegel, comes to mind: "If the facts contradict my theory, it is worse for the facts". After all, the artistic model of thinking has to some extent outstripped the psychoanalytic one. The reason for this may be the neglect of the true nature of human existence. In "The Critique of Psychoanalysis", A. Grunbaum compared the power of the influence of religious beliefs with psychotherapeutic teaching. He noted that Freud doubted the competition of psychoanalytic methods with religion, since he believed that those who "believed in the miracles of Virgin Mary more than those who believed in the unconscious". Although psychoanalytic and Christian ideas about the anthropology of the unconscious and therapy are the same, according to A. Grunbaum, the culturally influenced psychoanalysis would be defeated by theology.

Christianity refers to the three-dimensional nature of human: the body (it is impossible to perceive the personality without it), the soul (mind, will, heart (feelings)) and the spirit generated by prayer and the Holy Spirit. The soul is closer to the body, and the spirit to God. The spirit has those constituents that the soul, but on another level.

However, in modern Ukrainian literary criticism there is a false view: there seems to be a conflict of interpretations between psychoanalysis and Christian anthropology, which makes their methodological combination impossible. The complex of appropriate maxims is artificially instilled by the atheistic thought of the so-called confrontation between faith and science $^{10}$. In this regard, N. Zborovska observes: "The code of Ukrainian literature is created by the archetypal writers. A characteristic feature of archetypal creative psychology is the holistic love introjection of the parent-maternal code which in the mental matrix refers to the archetype of God, the Father, and, from the point of view of psychoanalysis, constitutes the unity of the unconscious (maternal instinct) and the conscious (parental inheritance of courage). Archetypal writers, being the bearers of the monotheistic religious tradition (i.e. Christianity - A.P.), orient the people

8 Див.: Томэ Х. Кэхеле Х. Современный психоанализ: В 2 т. Москва: ПрогрессЛитера-Яхтсмен, 1996. Т. 1. 576 с.

${ }_{9}^{9}$ Грюнбаум А. Критика психоанализа. Вопросы философии. 2007. № 3. С. 111.

10 Див.: Мень А. О науке и религии. История религии: В поисках Пути, Истины и Жизни: В 7 m. Москва: СП „Слово”, 1991. Т. 1. С. 171-179. 
at spiritual interests, since the strengthening of spirituality leads to the strengthening of national character" $"$.

In general, the scientific importance of this position is that the author's self-expression is the main "semantic core" of the work for the recipient, that is, the understanding of the text of the works of art comes through the prism of religious (here Christian) spiritual values. Although in conditions of mutual artistic code, the direction of psychoanalytic interpretation changes, its constant can be graphically reproduced as follows: the author (Id, Ego, Super-Ego) as a medium of the collective unconscious (Self) / society / text / work / reader.

The psychoanalytic aspect deals primarily with the dynamics of the identity of the multifaceted nature of the author's Self with the "function" of the character as a figure of the unconscious, which is a complex phenomenon of a person dependent on the course of transfer, projection, transportation, counter-transference, distancing, and other psychological mechanisms. Therefore, the problem of the aesthetic transformation of the author's "internal biography" arises, which is always differential by nature. M. Bakhtin noted that "when a person is in art, he/she is not in life, and vice versa" $"$. Because between them there is no unity and inner interpenetration into the spiritual world of personality. Thus there appear the psychoanalytic problems of two-dimensional (body, soul) anthropological dialectics in literary activities connected with the interpretation of the spiritual inner world of human.

\section{The prospect of two-dimensional anthropological dialectic in psychoanalysis and literary activities}

It is natural that after the advent of psychoanalysis as a science in the early twentieth century, the very internal logic of analytical and literary thinking began to change modelling numerous postulates in literature studies. After all, the scientific substantiation of the notion of the unconscious as a psychic reality, the Oedipus complex, the primary scene and the conflict dramatically changed the traditional views on the psychology of creativity in general.

However, at the turn of the twentieth century, in cultural life of society, including Western Europe, the crisis of human identity deepened: I-for-Self was more important than I-for-Other. In contrast to Franko's "faith in the

11 Зборовська Н. Код української літератури: Проект психоісторії новітньої української літератури. Київ: Академвидав, 2006. С. 471.

${ }^{12}$ Бахтин М. Эстетика словесного творчества. Москва: Искусство, 1986. С. 7. 
power of the spirit and the resurrected day", the French modernist poet Paul Valerie defined the artistic text as a "body" that exists only as an aesthetic form, a symbolic temple of human being. The contemporary interpretation of the metaphysics of the artistic landscape as "a text that opens in the space of reading", according to V. Podoroha's interpretation, "is our second body, which we again and again wish to possess"13. This gives rise to the hedonistic setting of the individual, the so-called aestheticization of "embodied" love.

Oedipal thinking as a manifestation of the two-dimensional anthropological dialectics reaches the horizon of the expanded "decameronic" paradigm of literary activities, meaningful carriers of which within limits of any psychoanalytic interpretation are plot-making of morbid jealousy ("Othello" by W. Shakespeare), compulsive hoarding ("Gobsek" by O. de Balzac, "Dead Souls" by M. Gogol), kleptomania ("Pantalakha" by I. Franko), neronism ("Apple Blossom", "Black Panther and White Bear" by V. Vynnychenko), impotence phobias ("Don Juan or Stone guest" by J.-B. Moliere), unconscious rape in a state of ecstasy ("Snow" by M. Cherniavskyi); prostitution, which gives rise to the feelings of oppressive guilt ("Death" by M. Mohylianskyi); marriage of convenience, which leads to the secret paths of another's heart ("Sinner" by L. Martovych); an inner desire to raise children without a husband (V. Vynnychenko's "Mysterious adventure"), etc. Such fatal consequences outline the archetypal transformations of the collective unconscious rooted in the ancient customs of the peoples of the world.

The peculiar "family code" of orgy morality represents the taboo of pagan consciousness, its "primary participation mystique (mysterious participation) to the flock" (K.-G. Jung), because the distorted architecture of the collective soul contains the experience of feelings obtained by humans sinful in typical situations. The ritualization of exhibitionist inclinations is, to a certain extent, a group-based pathologic, protective mechanism against a depressive state, which gives the individual a psychological relaxation effect, weakens the intensity of feeling his/her Self before the moral imperatives of the conscience or the punishing eye of the "outsider". The frustrated need to be accepted by others has undergone exhibitionist metamorphoses. In order to negate the fear of conscience and avoidance of guilt, participants of the orgies did not hide their actions from others. The solution programmed by the society is replaced with the

13 Подорога В. Метафизика ландшафта. Коммуникативные стратегии в философской культуре XIX-XX века. Москва: Наука, 1993. С. 16. 
sexually orgiastic one and helps avoid remorse because it is disapproved by "many".

The inner core of neurotic manifestations of the collective unconscious has introspective nature. In the understanding of the individual's mythological consciousness, the "body" is a metaphor. K.-G. Jung focused on the estrangedness and loneliness of the modern human, every step of whom is an effort to free him/herself from the unconscious in which most people are. The individual is constantly experiencing a condition characterized by the contradiction of body and mind. If reconciliation with the truth becomes possible (the essence of which is that the spirit is the life of the body and is known from within, and the body is the outward manifestation of the life of the spirit), then, in Jung's opinion, it will be revealed to us "why attempting to transcend the present level of consciousness by accepting the unconscious must give the well-deserved to the body, and why recognition of the body does not allow the philosophy which refuses it for the sake of the spirit" ${ }^{\prime 14}$.

This contradiction reveals the "vulnerability" of the two-dimensional dialectics of the psychoanalytic paradigm. After all, the current process of therapeutic situation "here-and-now" is ineffective in restructuring the neurotic nature of the person into the positive direction, because analysts perceive the negative state of the unconscious in a person for mental reality, which is not subject to the spiritual and moral criteria. It levels the possibility of purification and sanctity of the soul that can be performed in the Christian perspective of Eternity.

According to psychoanalysis, passion cannot be overcome in human, so in the spiritual paradigm, the victory over it is possible with the help of God. St. Anthony the Great claimed to be based on the material contained in the body. However, a soul which is deprived of material burdens knows God, watches over his/her body, and does not trust him/her. Thus, in this psychoanalysis confronts Christianity using its methods of "anticonfession", the essence of which is to concentrate the patient on those psychological processes that take place in a particular place and time, that is, on actual interpersonal relationships and feelings. This approach will only be effective if the analyst understands what is happening, how it is happening and why. In the literary and artistic context, the narrator helps the character to comprehend himself/herself, to attain authenticity to his/her metaphorically pure Self, and the recipient, being in the complex

14 Юнг К.-Г. Сознание и бессознательное: Сб. Санкт-Петербург: Университетская книга, 1997. С. 498-499. 
dialectics of "understanding-through-other", tries to reconcile his/her own "code of art" with the author's one.

A lot of scholars believe that psychoanalysis has turned into a paradigmatic worldview science of synthetic nature, a new "social institution". The main methodological role of deductive and inductive approaches in clinical and applied psychoanalysis was played by Freudianism, which, in deep psychology, became the main "marker" of science, the nucleus of which is topical (unconscious, subconscious, consciousness), structural (Id, Ego, Super-Ego) and dynamic models of understanding the human psychic apparatus modified by the archetypal theory of K.-G. Jung and the linguistic structuralism of J. Lacan et al. This resulted in an atheistic outlook on the modification of the psychoanalytic paradigm.

Considering the milieu and epoch, K.-G. Jung came closer to the truth of the matter. He sent the believers, who came to him for a reception with internal complaints, for confession to the priest. As a result, the least number of complex neurotic and psychiatric illnesses were found in believers, Catholic parishioners. So, within forty years of psychotherapy practice of K.-G. Jung, among the believers "there were no more than six people who actively professed Catholicism"15. In view of this fact, he stated: "The remission of sins, the Holy Communion can heal them [the patients - A.P.] even in very serious cases. If the experience of the Holy Communion is real, if the ritual itself and dogma fully express the psychological situation of a particular individual, he/she will be cured. Therefore, if the ritual and dogma do not fully express the psychological situation of the individual, he/she will not be cured"16.

Jung's explanation of the sacred mysteries was based not on the inward Christian faith, but on the rational basis of the belief that "for many years, Catholic pastors have studied psychotherapy and in many cases adhered to its rules"17.

Influenced by occultism as well as various pseudoreligious ideas, K.-G. Jung did not understand the true Christian faith. In the spiritual world, he showed the same understanding of the nature of the human psyche as $\mathrm{S}$. Freud in the materialistic one. A lot of contemporary scholars traced this trend in the religious and cultural concept of K.-G. Jung: “...the Swiss thinker sought for his doctrine of the collective unconscious to create a prototype of the religion of the future - the so-called "natural theology

\footnotetext{
${ }^{15}$ Юнг К.-Г. Символическая жизнь. Москва: Когито-Центр, 2003. С. 297.

${ }^{16}$ Там само. С. 304.

${ }^{17}$ Там само. С. 299.
} 
that could replace all existing religions and revitalize the human spirit, introduce an element of inspiration and spirituality" ${ }^{\prime 18}$.

These plans of K.-G. Jung state his narcissistic tendency. After all, the apocalyptic idea of uniting all religions leads to the disappearance of the Truth, which states that every person must "write his/her Gospel" with his/her own life (H. Planchak).

In general, the scientific importance of the psychoanalytic paradigm of human destructiveness is concentrated in the teaching of the Holy Fathers about the eight basic passions of sinfulness, first mentioned in the writings by Evagrius Ponticus. Subsequently, the official Christian doctrine of the Eastern (Orthodox) and Western (Catholic) Churches began to be based on these guidelines. For example, in 590, Saint Pope Gregory the Great, modifying the sequence and number of the corresponding passions of these people, called them "mortal sins", which are the result of the original damage to the soul of human during the times of Adam and Eve. The Apostle John assured that "there is also a sin unto death..."

In theological methodology, the Western concept of the "seven deadly sins" has been greatly expanded, which caused in the fourteenth century to the creation of the Catholic mnemonic rule SALIGIA named after the first letters of Latin names of the passions. The following classic paradigm of the gradation of the "seven deadly sins" and the opposing virtues was constructed:

1. Superbia (arrogance) - humility;

2. Avaritia (parsimony) - generosity;

3. Luxuria (fornication) - restraint;

4. Invidia (envy) - benevolence;

5. Gula (gluttony) - temperance;

6. Ira (anger) - gentleness;

7. Acedia (laziness) - diligence.

Saint Ephraim of Syria interpreted the contradictory duality of human nature. He assured that "the beginning and the end of the good is humble wisdom (humility. - A. P.), so the beginning and end of the evil is arrogance" 20 . This explains the spiritual salvation of the robber crucified near Christ and justified without good deeds in the sight of God unlike the

18 Див.: Бичатін C. Релігійно-культурологічна концепція К.-Г. Юнга: Дис. канд. філос. наук: 09.00.11 Бичатін Сергій. Київ, 2002. 174 с.

${ }^{19}$ Біблія або Книги Святого Письма Старого й Нового Заповіту. Пер. з давньоєвр. й грец. І. Огієнка. Київ: Українське Біблійне Товариство, 2009. [Ів.: 5; 16]. C. 376.

${ }^{20}$ Симфония по творениям преподобного Ефрема Сирина. Москва: Даръ, 2008. 
"righteous" Pharisees who, through their own arrogance, lost their former good deeds. Therefore, "he who loves humility, it is so easy to love God, and he who loves arrogance hates God"21.

Thus, the teachings of the Holy Fathers about the seven (in Eastern Christianity - eight) basic passions reveal the mystery of human existence: the appearance of evil, ways of combating it, the causes of the Fall, and so on. Answering these topical existential questions, they point to the wrong psychological setting of most people who seek the Evil in external circumstances: the injustice of legislative and executive powers, lack of material goods in society, aggressive wars, criminal activity, etc. Hieromonk Mikhail Pitkevich instructed: "Do not seek the truth on earth... seek it in yourself..."22. That is, one must first and foremost correct one's inner damaged human nature aimed at satisfying passions, the causes of sins.

The word "passion" in Church Slavonic is translated as "suffering". It is necessary to fight it, especially through the sacraments of the Church and prayer, with good deeds, so that at the end of one's life one can say in the words of the Apostle Paul: "I do not live already, but Christ lives in me".

In the literary work of the Italian Renaissance, the "seven deadly sins" are described in detail in the poem "Divine Comedy" by Dante as circles of the purgatory, which is viewed by the main character. It follows that the inner world of the artist is open to both Heaven and Hell.

In real life and literary activities, human passions and virtues are not differentiated, but synthetic. Therefore, the aesthetic function of literary activities does not, in essence, contain the ethical principle of seeing in its "pure form", so the two-dimensional dialectics of coherence and difference between Christian-theological and psychoanalytic paradigms in the context of artistic texts should be considered. The gradation of the "seven deadly sins" implies a close relationship between psychotherapeutic (analytical) and social levels of human life, which can be graphically reproduced in the form of a table (Table 1.):

21 там само. С. 373.

22 Цит. за: Ново-Дивеевская М. Сказочка о правде отца Михаила (Питкевича). Беседы великих русских стариев. О православной вере спасении души и различных вопросах духовной жизни. Полтава: 3АО, 2007. С. 1320. 


\section{The correlarion of the "seven deadly sins", diagnoses and destructions in society}

\begin{tabular}{|c|c|c|}
\hline "Seven Deadly Sins" & $\begin{array}{c}\text { Main and concomitant } \\
\text { diagnoses }\end{array}$ & $\begin{array}{c}\text { Destructive signs } \\
\text { of the society }\end{array}$ \\
\hline Arrogance & $\begin{array}{c}\text { Narcissistic neurosis, } \\
\text { megalomania }\end{array}$ & "Class" inequality \\
\hline $\begin{array}{c}\text { Miserliness } \\
\text { (money-loving) }\end{array}$ & The accumulation mania & Social poverty \\
\hline Fornication & $\begin{array}{c}\text { Perversion, marital } \\
\text { maladaptation }\end{array}$ & Family breakup \\
\hline Envy & Inferiority complex & The invading wars \\
\hline Gluttony & Bulimia & $\begin{array}{c}\text { Drug-addiction, } \\
\text { alcoholism }\end{array}$ \\
\hline Anger & Depression & $\begin{array}{c}\text { Suicide thoughts, } \\
\text { isolation }\end{array}$ \\
\hline Laziness (passivity) & Apathy & $\begin{array}{c}\text { The desire to live at the } \\
\text { expense of others }\end{array}$ \\
\hline
\end{tabular}

Passions, diagnoses and social consequences are interrelated, which makes it impossible to say that they are adequately identified in "pure form" (as set out in Table 1.). For example, the cause of invasive wars is the prerogative of not only envy, but also anger and arrogance. Depression can be caused not only by aggression, but also by arrogance, fornication, avarice, etc. Apathy is accompanied by laziness as a result of atrophied willpower only when the absence of ordinary emotional experiences and existential indifference can be traced. V. Leibin notes that apathy emerges as a result of the protective mechanisms of the Self that contribute to the neutralization of intra-psychic conflicts through changes in life settings; their presence negates the desires and needs of human ${ }^{23}$.

In Christianity, an alternative to this paradigm of human passions is seven virtues: faith, hope, love, wisdom, courage, righteousness and moderation, among which, as the Apostle Paul assured, "the greatest is love ${ }^{, 24}$.

The "norm" of human nature from the point of view of Christianity is the "experience of holiness" which corresponds to the Gospel truths. Instead, psychoanalysis has different views on the standard of a mentally

${ }^{23}$ Див.: Лейбин В. Словарь-справочник по психоанализу. Санкт-Петербург: Питер, 2001. С. 49.

${ }^{24}$ Біблія або Книги Святого Письма Старого й Нового Заповіту. Пер. $з$ давньоєвр. й грец. І. Огієнка. Київ: Українське Біблійне Товариство, 2009. [1 Кор. 13: 13] 
healthy person. Three basic theories are known: 1) the "norm" is called what is "habitual to a particular culture" 25 (K. Horney); 2) in connection with the degradation of society, the development of "individual and social narcissism"26 (E. Fromm) "norm" is relative, i.e., in each case, it is considered separately; 3) "norm" as such does not exist at all; it has been lost since the time of the original religious-cultural and social formations, as factors of "mass psychosis",27. (S. Freud). Thus, the absurd idea of Freud is the truest, because in spite of it, the author suggests the perfect nature of the first man on Earth - Adam.

Thus, in psychoanalysis there is no definite notion of mental "norm", but only "psychopathology". This has led to the fact that analysts" interpretations often identify dignity with arrogance, humility with depression, egocentrism (narcissism) with self-affirmation of personality and so on. N. Vasylieva, as a psychologist and forensic expert, argues that mentally ill people are less capable of criminal behaviour than healthy people, which is also confirmed by the statistics. After all, psychology as a science does not provide an identical one-hundred-percent guarantee in determining the diagnosis by mental symptoms. S. Freud claims that the symptoms of neurosis are an echo of the human conscience, pangs of conscience. In Christianity, it is argued that human illness and suffering are not devoid of existential meaning and are not always the result of man's sinfulness, but above all, it is God's test which must be accepted with gratitude as a means of healing for the sin-damaged soul. Consequently, the psychoanalytic two-dimensional dialectics (bodily and mental) of understanding the mental complexes or the neuroticization of a person's internal conflicts is not as perfect as the Christian's three-dimensional one because it does not take into account the spiritual nature of the individual. Archimandrite Sophronius considered sin to be a spiritual, metaphysical phenomenon. He found its origins in the mystical spiritual nature of a human and the nature in the distance from the divine life which we are created and designed for by our nature.

Sin affects the mental and physical states of human; his/her appearance; the fate of this person and the fate of the whole world. A person is not capable of recognizing changes in themselves after committing original sin, since he/she is always in spiritual death and has not known the eternal life of the spirit. This is the cause of human helplessness in the passions and instincts.

25 Хорни К. Психология женщины. Самоанализ. Психология женщзины. Новые пути в психоанализе. Санкт-Петербург: Питер, 2002. С. 160.

${ }^{26}$ Фромм Э. Душа человека. Москва: Республика, 1992. С. 47.

${ }^{27}$ Фрейд 3. Введение в психоанализ: Лекции. Москва: Наука, 1991. С. 400. 
This is the imperfection of Freud's psychoanalytic heuristics with the dilemma of endless and complete therapy, with the inability to achieve functional unity between theory and practice, and hence methodological normality. However, the artistic resources of human thinking are greater than scientific ones. Subsequently, F. Schiller, considering the idea of language as a closed system without which there is no thinking, ironically remarked: "The language thought and felt for him". In "Poetry and Truth", W. Goethe noted that theory and practice are interconnected: from the actions of people one can understand what they think and from their thoughts - predict what they will do. Literary activities are a confirmation of this tenet.

\section{CONCLUSIONS}

In our interpretation, interdisciplinary intertextuality is the principle of constructing the psychoanalytic paradigm of literary activities, which contains in the literary reception a synthesis of Christian trichotomy (body, soul, spirit) with a psychoanalytic two-dimensional (body, soul) dialectics about the human's nature studying. The literary tools updated at the same time allow us to more adequately and deeply understand and explore the anthropology of the unconscious psychic in literary and artistic dimensions.

The perspective of psychoanalysis and literary activities is in the interdisciplinary integration of Christian ethics, the essence of which is an in-depth study of the three-dimensional dialectics (body, soul, spirit) of true human nature.

What is the interdisciplinary integration of psychoanalysis, literary activities and Christian ethics? Research objectivity lies in the fact that certain discoveries in psychoanalysis and their expression in art creativity, namely the role of the unconscious, Oedipal complex, transfer, opposition, primary stage and other mechanisms and structural bodies of the human psyche in the therapeutic process are related with the Christian universal of church confession for the solution of the internal problems of the human soul. Psychoanalysis, theology and literary activities operate with different concepts: psychosis, neurosis, complex, sinfulness, passion, original and ancestral sins, character/protagonist, climax, dramatic conflict, solution, and so on, but in fact, they offer the same therapeutic and healing content, the end result of which, from the point of view of Christianity, is repentance, in psychoanalysis - insight, and in literary activities catharsis. 


\section{SUMMARY}

The paper deals with the problems and perspectives of psychoanalytic interpretation of literary activities. Primarily it discusses the overcoming of stereotypes concerning methodological foundations of interdisciplinary integration of Christian anthropology and psychoanalysis, opening significant new existential and psychological facets of classical writings in the world literature. The paper focuses on the basic tenets of Christian ethics, which are most closely related to psychoanalysis, because they interpret the human psyche at the deep level and assure that every thought, feeling and action have their reason at the conscious and unconscious levels.

\section{REFERENCES}

1. Антонич Б.-І. Криза сучасної літератури. Сучасність, 1992. № 9. C. $71-72$.

2. Бахтин М. Эстетика словесного творчества. Москва: Искусство, 1986. $445 \mathrm{c}$.

3. Бичатін С. Релігійно-культурологічна концепція К.-Г. Юнга: Дис. канд. філос. наук: 09.00.11 Бичатін Сергій. Київ, 2002. 174 с.

4. Біблія або Книги Святого Письма Старого й Нового Заповіту. Пер. 3 давньоєвр. й грец. І. Огієнка. Київ: Українське Біблійне Товариство, 2009. $1151 \mathrm{c.}$

5. Грюнбаум А. Критика психоанализа. Вопросы философии. 2007. № 3. C. 105-129.

6. Зборовська Н. Код української літератури: Проект психоісторії новітньої української літератури. Київ: Академвидав, 2006. 504 с.

7. Лейбин В. Словарь-справочник по психоанализу. Санкт-Петербург: Питер, 2001. 688 с.

8. Мень А. История религии: В поисках Пути, Истины и Жизни: В 7 т. Москва - Санкт-Петербург „Слово”, 1991. Т. 1. 287 с.

9. Мень А. О науке и религии. История религии: В поисках Пути, Истины и Жизни: В 7 m. Москва: СП „Слово”, 1991. Т. 1. С. 171-179.

10. Ново-Дивеевская М. Сказочка о правде отца Михаила (Питкевича). Беседы великих русских стариев. О православной вере спасении души и различных вопросах духовной жизни. Полтава: ЗАО, 2007. С. 1320-1321.

11. Подорога В. Метафизика ландшафта. Коммуникативные стратегии в философской культуре XIX-XX века. Москва: Наука, 1993. $319 \mathrm{c}$.

12. Пурло Е. Естественнонаучные парадигмы в психологической науке: клас-сическая, неклассическая и постнеклассическая модели. Практична психологія та соціальна робота. 2007. № 5. С. 15-24. 
13. Савчин М. Методологічні та практичні проблеми психотерапії у контексті духовної парадигми психології. Психологія і суспільство. 2009. № 4. C. 229-241.

14. Симфония по творениям преподобного Ефрема Сирина. Москва: Даръ, 2008. 480 с.

15. Ткачук М. Наративні моделі українського письменства. Тернопіль: ТНПУ, Медобори, 2007. 464 с.

16. Томэ Х. Кэхеле Х. Современный психоанализ: В 2 т. Москва: Прогресс- Литера-Яхтсмен, 1996. Т. 1.576 с.

17. Фрейд 3. Введение в психоанализ: Лекции. Москва: Наука, 1991.465 с.

18. Фрейд 3. Художник и фантазирование. Воспоминания Леонардо да Винчи о раннем детстве. Санкт-Петербург: «Азбукаклассика», 2007. С. 199-216.

19. Фромм Э. Душа человека. Москва: Республика, 1992. 430 с.

20. Хорни К. Психология женщины. Самоанализ. Психология женщиины. Новые пути в психоанализе. Санкт-Петербург: Питер, 2002. С. $13-168$.

21. Цвейг С. Фридрих Ницше. Зигмунд Фрейд: Эссе. СанктПетербург: Азбука-классика, 2001. 224 с.

22. Юнг К.-Г. Символическая жизнь. Москва: Когито-Центр, 2003. $326 \mathrm{c}$.

23. Юнг К.-Г. Сознание и бессознательное: Сб. Санкт-Петербург: Университетская книга, 1997. 544 с.

Information about the author: Pecharskyi A. Ya., Doctor of Philology (Habil.), Professor at the Mykhailo Vozniak Ukrainian Literature Department, Ivan Franko National University in Lviv 1, Universytetska str., Lviv, 79000, Ukraine 